\title{
Post-modern changes in marital and family life
}

\author{
Agata Kozak \\ agata22kozak@gmail.com
}

\begin{abstract}
Contemporarily, the traditional model of marriage is no longer the only accepted form of family life; there are many alternatives to that type of relationship. In post-modernity we face a rapid change in the perception of informal relationships as well as their dynamic development and increase in number. However, will cohabitation - which in the times of moral relativism, praise of freedom and individuality and democratisation of all aspects of human life becomes increasingly popular - eventually dominate and replace traditional marriage?
\end{abstract}

Key words: post-modernity, intimate relationships, marriage, cohabitation, sexuality

Contemporarily, one can observe rapid changes in all aspects of human life. Many researchers claim that with the turn of the twentieth century the era of modernity ended, and the period of post-modernity began. It is connected with changes in all crucial areas - society, economy, and culture. When considering the changes in marital and family life, one cannot ignore the peculiarities of post-modernity. The processes that characterise contemporary reality are individualisation, decreasing of the role of institutions, democratisation, and the plurality of standards and values. "Today individuals are 'socially engaged' primarily through their role as consumers, not producers; the arousing of new desires replaces normative regulation, publicity takes the place of coercion, and seduction makes redundant or invisible the pressures of necessity. In this kind of context the stiff and resilient structures of the »till death us do part « type, indispensable in the panoptic system of power, lose their usefulness" (...) (Bauman 1997, p. 143); this forces one to live the life of a vagabond, who never becomes attached to places and considers interpersonal relations a series of unconnected events unimportant episodes. Axiological emptiness and hedonistic attitude lead to the decline of the sense of security and a futile search for ethical norms - “(...) this is certainly true about commonly agreed ethical rules, such as we can also hope to be commonly observed: such rules as may guide our conduct toward each other - ours towards others and, simultaneously others towards us - so that we may feel secure in each other's presence, help one another, co- 
operate peacefully and derive from each each other's presence a pleasure untainted by fear and suspicion" (Bauman 1993, p. 16). All these factors lead to the search for new forms of interpersonal relations, more suited to the present day than marriage. Is it possible, then, for informal relationships, with their dynamic development and increase in popularity, to dominate and, in turn, replace marriage?

The traditional, homogeneous model of marital and family life has decreased in importance in the face of modern and post-modern change. The authoritarian, patriarchal, multifunctional and multigenerational traditional family, with the father as its sole breadwinner, has turned into a nuclear, democratic, independent, not numerous contemporary family. For ages marriage and family have constituted integral elements of the social order. The roles and expectations of the genders were laid down in minute detail and regulated everyday life, enterprise and sexuality (Slany 2002, p. 53-54). Contemporarily, social norms do not interfere so radically with family life, and the roles and expected behaviours are determined by individual needs and the situation of the family. The sexual revolution and the change of the woman's role in society have constituted the most important reasons for the departure from the traditional model and the introduction of modern models of the family. The liberalisation of sexuality has freed women of their archaic roles as passive, asexual domestic slaves, dependent on men and devoid of civil rights. The age-long conviction that a man should have a rich - often extramarital - sex life, and a woman's sexual experience should be limited to intercourse with the husband has been rejected. The myth of submissive woman, for whom sexual intercourse is devoid of pleasure and exclusively constitutes a marital duty has collapsed, as well. The sexual revolution has led to the pursuit of equal rights and the right to vote for women, as well as the chance to govern their lives and bodies. The emancipation movement paved the way for education and professional careers for women, which has shaken the foundations of the family roles. The position of the man as the head of the family has weakened, and the woman has broken the shackles of domestic slavery. According to Z. Bauman, sex used to be a foucaldian relationship instrument used for the construction of family structure and marital partnership. Nowadays it serves to weaken the structure and to reduce marital responsibilities (Slany 2002, p. 97). The assumption that marriage is a fundamental socio-economic unit legitimising sexual intercourse has been abandoned altogether. Thenceforth, marriage has no longer been considered a community of interests, and one would get married because of love, not calculation. The sexual revolution has also led to the growing popularity of contraceptives, and the separation of sexual and procreative functions. The economic and social independence of women from men, the 
progress in planned parenthood and the increased importance of satisfaction and fulfilment in a relationship have questioned the durability and indissolubility of the marital "bond". Financial independence of women along with the legal permissibility of divorce allow for women who are not housewives provided for by their husbands to make use of that opportunity when the partner fails to meet expectations or the feelings between the married couple die out (Szlendak 2002, p. 292). Durability of marriage has been reduced to the calculation of gains and losses resulting from remaining in the relationship or breaking it up and entering a new one. All those changes of marital and family life have led to the search for new, alternative models of living as a couple.

Contemporarily, one can observe a constant increase in the number of informal relationships, in Western Europe as well as in Poland. Both in legal and colloquial terms this model of interpersonal relationship is to be named a "concubinage". This term of Latin origin (com cubare - "sleep together") is to be defined as a stable relationship between a man and a woman that does not involve marriage (Sobol 2003, p. 349). Because of the pejorative connotations of the term in informal language it is proposed to employ instead the term "cohabitation", as used in sociological and psychological publications. For the sake of simplicity cohabitation shall be defined as the living together of two unrelated adult people in a sexually intimate relationship, who run a household, without legalizing the relationship (Szukalski 2004, p. 49). Many reasons have been discussed for why people prefer informal relationships to marriage. For young people cohabitation is an attempt at living together, which eventually becomes engagement. This type of cohabitation constitutes the first level of marriage, as in the two-level marriage model, as proposed by M. Mead - the first level being the intimate marriage, occurring between a man and a woman who do not plan to have children in the immediate future; the second level being the family marriage that occurs for the sake of the already born children (Szlendak 2002, p. 299). That is the most common form of informal relationship; the percentage of people under 29 years of age involved in open relationships has increased in Poland over the last few years, with a decrease among people aged 30 to 39 and 40 to 49 . Cohabitation is chosen as an alternative to marriage by divorced people who have had the experience of unsuccessful marriage. However, both forms are impermanent. L. Bumpass and J. Sweet claim that $40 \%$ of all first relationships break up within a period of 10 years. The break-up index of all first cohabitations is almost twice as high as that of first marriages (57\% to $30 \%$ respectively). $29 \%$ of cohabitations and $9 \%$ of marriages break up within 2 years. Only $10 \%$ of informal relationships last longer than 10 years (Kwak 2005, p. 171). Furthermore, according to M. Castells, almost half of all 
cohabitations end within a year, and $40 \%$ become formal marriages, out of which $50 \%$ end in divorce, with $2 / 3$ of the people involved entering new marriages with a high probability of divorce (higher than in all marriages in general) (Slany 2002, p. 147). Researchers also mention the problem of "serial cohabitants" - people whose successive informal relationships become increasingly unstable. It is often emphasized that the forming and breaking up of such relationships is easy; however, this approach fails to recognise the legal problems connected with the breaking-up of an informal relationship. That is the reason why many countries in Western Europe attempt to introduce regulations granting open relationships a legal status. In 1999 France introduced the Civil Pact of Solidarity (PACS) which grants to cohabitation the rights of marriage. Partners who have lived in such a relationship for at least 3 years have the right to a common income declaration, tax relief, health insurance and the right of inheritance (Piechnik-Borusowska 2001, p. 61). The agreement may, however, be cancelled through a decision of only one of the partners. In 2001 Belgium introduced the "legal cohabitation" law that puts the partners under an obligation to take mutual responsibility for their household, although it grants them no right of inheritance. In Poland it is commonly believed that regulations concerning marriage should not be applied to informal relationships (PiechnikBorusowska 2001, p. 62). No legal regulations concerning cohabitation have been introduced. According to the Family and Guardianship Code cohabitants have no alimony obligations - if one of the partners falls ill or loses a job, the other can leave with no legal consequences. People in informal relationships do not look ahead; they do not think or worry about how their possessions would be divided in case of a break-up. The willingness to have children is yet another problem. Marriage is still considered the proper environment for having and raising children (Kwak 2005, p. 173) - that is why cohabitants are less willing to have children, which makes them more akin to people in a single state, rather than married ones. Research findings demonstrate that having a child leads to the legalisation of the relationship, with the cohabitations that have not turned into marriages being the most fragile, 1 in 5 breaking up before the child turns 5 (Slany 2002, p. 162). In case of a break-up one of the partners can sue the other for child alimony; one cannot, however, expect compensation from a partner who fails to provide for the family. Furthermore, in the event of one of the partner's deaths, the other will not receive a dependent's pension, with inheritance being yet another problem. According to the Polish law of succession it is not possible to bequeath all possessions to one's partner (that is, legally, a stranger), since the lawful heirs (the family) are to receive a legal portion. What is more, a cohabitant cannot receive the inheritance tax relief - this usually implies that one has to pay a higher tax rate. 
One of the frequently mentioned positive aspects of being in an open relationship is personal independence and the opportunity to cultivate one's individuality, which is said to be impossible in a marriage. The roles and the ways of their realisation are up to the partners themselves - a cohabitation can be based on the traditional model, whereas a marriage can be based on the fully democratic model of community. Furthermore, relationship is defined as the interaction of different combining elements, influencing and affecting one another integrity, union, connection (Sobol 2003, p. 1297); that is why it requires of one to give up a part of one's individuality and independence for the sake of unity. It is a mistake to consider cohabitation as more democratic than marriage, since democracy is essentially a common decision-making and respect for the rights of other people, rather than concentrating on the fulfilment of one's own needs. There needs to be a bond, mutual respect and honesty between two people in order for them to have a relationship, and a fundamental rule constituting a democratic relationship is that there are no rights without obligations. One can observe a difference between how this aspect is perceived by men and women. Men perceive informal relationship as requiring less dedication and less responsibility for the partner than marriage with its standards (Slany 2002, p. 150); for women, on the other hand, cohabitation is an introduction to marriage. Cohabitation may, than, be chosen because of the unwillingness to take up the obligation to take care of the partner and the responsibility for one's actions; it may be considered a way to fulfil one's egoistic needs.

In the context of intimate relationships, the questions of love and sexuality cannot be avoided. Nowadays, sexuality “(...) it is something each of us »has«, or cultivates, no longer a natural condition which an individual accepts as a preordained state of affairs" (Giddens 2002, p. 15), with the change taking place due to the acquiring of equal rights by men and women in regard to sexuality. The liberalisation of sexuality, along with the acceptance of premarital and extramarital sex as well as homosexual relationships has weakened the position of marriage, allowing, at the same time, for the development of alternative models of relationship. Mutual love, understood as something other than the realisation of the egoistic need to fill the existential emptiness through "consuming a partner" (Szlendak 2002, p. 297), and connected with care, intimacy and faithfulness is necessary to allow the sexual life of the partners to become an act of mutual giving and taking of sexual satisfaction. Love should not be reduced to a material possession or identified with the fulfilment of sexual desires, because it is a combination of three elements: intimacy, passion and dedication. In order for a relationship between two people to last, all these elements must be present - if they are not, the relationship will face an imminent end. Z. Bauman claims, however, that relationships nowadays are not 
established "in order to", as means to an end other than the relationship itself, but in expectation of benefiting from the relationship, in expectation of satisfaction that an intimate partner may provide. It would be absurd to expect such love, and especially a relationship devoid of it, to last longer than the mutual satisfaction of the partners (Slany 2002, p. 94). Therefore, in postmodern culture it is better to be "next to each other" rather than "together", with love considered a ludic game, careless play and adventure rather than dedication to a relationship. Post-modernity has introduced chaos into the set norms and standards of personal relationships, allowing, in the context of "subjectivity", for a hedonist reduction of a partner to a usable object. Consumption-oriented, valuing pleasure and instant benefit, disaccustomed, in the times of "consumption", from correcting anything, the young people give up the fight for a relationship as soon as "something goes wrong" - when sexual passion fades (Szlendak 2002, p. 296). In relationships, both marriages and cohabitations, there is no place for cheating, “ (...) that both men and women have an evolved psyche that is biased toward opposing a partner's infidelity. (...) If there is a risk of suffering, the preprogrammed psyche will surface and destroy even the most determined of »open« relationships" (R. Baker 2000, p. 43). Nowadays, our drives, freed of the shackles of restrictive standards by the sexual revolution, bring forth chaos, leading to a crisis of identity. We can be married and still have many lovers, we can live in separation, we can divorce, and then remarry. We can form a threesome with the husband's or the wife's lover, we can live with a group of friends and raise children together. We can shoot amateur porn films at home, with us as actors, and distribute them via the Internet. We can take part in swingers' parties, once we become completely bored with our sexual life as a couple. We can drown our loneliness in watching pornographic images, to be bought in a sex-shop right around the corner, or play erotic games on a PC. We can buy all sorts of sexual services, we can use the partners we happen to meet at a disco for a moment of ecstasy, like, as it were, a new cell phone (Szlendak 2002, p. 312). However, don't we need some sort of guidance in the labyrinth of momentary sexual passions?

In the times when man - with his subjectivity, freedom of choice, individuality becomes the ultimate value, we try to come up with new forms of intimate relationship, driven by our desire for personal happiness - at the expense of other people. Nowadays, in times of instability, of a multitude of possibilities and ways, of moral and axiological relativism, people tend to feel threatened. "In so many situations in which the choice of what to do is ours and apparently ours alone, we look in vain for the firm and trusty rules to be in the right. We would dearly wish to shelter behind such rules (even though we know only too well that we would not feel at all comfortable were we coerced into surrendering to them). It 
appears, however, that there are too many rules for comfort: they speak in different voices, one praising what the other condemns" (Bauman 1993, p. 20). Man, as a social being, needs guidance, ready-made models of interpersonal relationships that are not to be found in postmodern plurality. In this chaos one needs a point of support, a safe haven that provides a feeling of continuity; this can only be achieved through a renewed, institutional stability marriage. In this context, the history of interpersonal relationships goes full circle - from the traditional family model, with the man having the ultimate power over the woman, through the manifold intimate relationships, to marriage that is as far removed from the feudal structure of gender roles as it is from the post-modern "sexual chaos".

\section{Bibliography}

Baker R. (2000), Sex in the future. The reproductive revolution and how it will change us, Arcade publishing, New York.

Bauman Z. (1993), Postmodern Ethics, Blackwell Publishers, Oxford.

Bauman Z. (1997), Postmodernity and its Discontents, Polity Press, Cambridge.

Giddens A. (2002), Sexuality, love and erotism in modern societies, Polity Press, Cambridge.

Kwak A. (2005), Rodzina $w$ dobie przemian: matżeństwo $i$ kohabitacja, Wydawnictwo Akademickie ,Żak”, Warszawa.

Piechnik-Borusowska J. (2001), Czy wolne zwiqzki będq alternatywa dla życia matżénskiego $i$ rodzinnego $w$ Polsce? (na przykładzie badań w województwie opolskim), „Edukacja Dorosłych" 2.

Slany K. (2002), Alternatywne formy życia matżénsko-rodzinnego w ponowoczesnym świecie, Wydawnictwo „Nomos”, Kraków.

Sobol E. (ed.) (2003), Nowy słownik języka polskiego, Wydawnictwo Naukowe PWN, Warszawa.

Szlendak T. (2002), Architektonika romansu. O społecznej naturze miłości erotycznej, Wydawnictwo „Oficyna Naukowa”, Warszawa.

Szukalski P. (2004), Kohabitacja w Polsce [in:] Warzywoda-Kruszyńska W., Szukalski P. (eds.), Rodzina $w$ zmieniajacym się społeczeństwie polskim, Wydawnictwo Uniwersytetu Łódzkiego, Łódź.

Warzywoda-Kruszyńska W., Szukalski P. (eds.) (2004), Rodzina w zmieniajacym się społeczeństwie polskim, Wydawnictwo Uniwersytetu Łódzkiego, Łódź.

Wojciszke B. (1998), Psychologia miłości. Intymność. Namiętność. Zaangażowanie, Gdańskie Wydawnictwo Psychologiczne, Gdańsk. 
